\title{
Norway's Readmission Agreements: Spellbound by European Union Policies or Free Spirits on the International Field?
}

\author{
Maja Janmyr \\ Faculty of Law, University of Bergen, Magnus Lagabøtes plass 1, \\ 5020 Bergen, Norway \\ e-mail:maja.janmyr@jur.uib.no
}

\begin{abstract}
This article offers an analysis of the objective and substance of Norway's readmission agreements in light of European Union readmission policies. It explores how readmission policy developments on the EU level also impact Norway's practice, and argues that EU practice influences Norway's work on readmission in three important ways. First, as part of a preventative strategic policy, Norway seeks to conclude readmission agreements with countries with which EU readmission agreements (EURA) exist. Second, EU visa facilitation agreements that are paired with EURAs form an indirect link between EU and Norwegian readmission agreements. Third, Norway uses the EURA-format as a basis for negotiations even with countries where no EURA exists. This article also examines Norway's participation in the EU Global Approach on Migration and Mobility (GAMM), and finds that it is limited by the GAMM being only tangentially within the Schengen cooperation, and also by national political perceptions about linking readmission and development aid.
\end{abstract}

\section{Keywords}

EU - Global Approach to Migration and Mobility - Norway - readmission agreements Schengen 
Readmission agreements are one of the oldest instruments used by states to control migratory flows, and are increasingly used to combat irregular migration within both the European Union (EU) and Norway. ${ }^{1}$ The 'Stockholm Programme', which establishes the EU's priorities in the Area of Freedom, Security and Justice for the period 2010-2014, specifically provides that 'an effective and sustainable return policy is an essential element of a well-managed migration system within the Union'. ${ }^{2}$ EU readmission agreements (EURAs) have been described as 'essential tools' in the 'fight against immigration'. ${ }^{3}$ Concluding bilateral readmission agreements with third countries is also among Norway's top priorities. ${ }^{4}$ While it is not a member of the European Union, Norway strives to harmonize its migration policies to match those of the EU and its member states. ${ }^{5}$ Today, it seeks close cooperation with the EU on almost all matters of immigration and asylum, and has prioritized close dialogue with the $\mathrm{EU}$ Commission with regard to the conclusion of readmission agreements. ${ }^{6}$

This article seeks to explore in what manner, and to what extent, readmission policy developments on the EU level also impact Norway's practice; in other words, what is the de facto influence of the EURAs on Norway's readmission practice? By elaborating on Norway's readmission agreements in light of

1 European Commission. Communication from the Commission to the European Parliament and the Council: Evaluation of EU Readmission Agreements, Doc. No. сом (2011) 76 final (23 February 2011) (Evaluation of Readmission Agreements), at 2; A. Roig and T. Huddleston, 'EC Readmission Agreements: A Re-Evaluation of the Political Impasse', 9 European Journal of Migration and Law (2007) 363-387 at 366-367. See also N. Coleman (2009), European Readmission Policy: Third Country Interests and Refugee Rights, Leiden: Martinus Nijhoff Publishers.

2 Council of the European Union (2010), 'The Stockholm Programme - An Open and Secure Europe Serving and Protecting Citizens', Official Journal of the European Union C115/8.

3 Council of the European Union (2011), Council Conclusions Defining the European Union Strategy on Readmission (Council Conclusions on Readmission). Doc. no. 11260/11 MIGR 118, at 2.

4 Ministry of Justice and Public Security (JD). Proposition to the Storting: Prop 1 S (2012-2013) (Prop 1 S (2012-2013)), para. 4.2.

5 JD (2009), Meld St. 9 (2009-2010) Norsk flyktning-og migrasjonspolitikk i et europeisk perspektiv (White Paper on Immigration), at 21; Ministry of Justice and the Police (JD). Proposition to the Storting: Prop 1 S (2011-2012) (Prop 1 S (2011-2012)), at 22. See generally V. Vevstad (2006), Utvikling av et felles europeisk asylsystem: jus og politikk, Oslo: Universitetsforlaget; J.P. Brekke (2011), 'Migrasjon og Integrasjon: Norges tilknytning til EU', Europautredningen, report no. 10.

6 JD (2009), White Paper on Immigration, supra note 5, at $77 \mathrm{ff}$. 
the EURAs, this article aims to offer a first academic analysis of Norway's readmission policy. The first introductory part of this article provides a brief overview of Norway's relationship with the EU with regard to migration issues in general, and return and readmission in particular. The article continues with an elaboration of $\mathrm{EU}$ and Norwegian target countries, as well as an exploration of how readmission agreements concluded on an EU-level influence Norwegian readmission agreements. Part three of this article concerns the negotiation of readmission agreements, and, in view of EU developments, examines particularly how, and to what extent, readmission is integrated into Norwegian foreign policies.

\section{Return and Readmission: Norway's Schengen and EU Relationships}

While Norway, as a non-EU member, is only indirectly ${ }^{7}$ linked to the Common European Asylum System (CEAS), ${ }^{8}$ the Schengen agreement establishes one of the strongest links between Norway and the EU structure. The Schengen cooperation ensures freedom of movement on European territory and a joint responsibility for guarding external borders. Norway participates at all consultation levels in the Schengen 'Mixed Committee': working parties, Strategic Committee of Immigration, Frontiers and Asylum (SCIFA), and permanent representatives (COREPER). ${ }^{9}$ When Norway and other associated states (Iceland and Switzerland) participate in the Mixed Committee, they have full participation and speaking rights, but no voting rights.

Through the Schengen cooperation, Norway is also formally bound by many of the EU's return policies. The Directive on Return, setting out common rules and procedures to be applied in EU member states and related Schengen countries for returning irregular third-country nationals and adopted by the EU in late 2008, is one example. It was adopted by the Norwegian Parliament

7 Norway's participation in the Dublin-cooperation is one important exception. See V. Vevstad (2013), 'Felles yttergrense og felles europeisk asylsystem', in: Ø. Øyen (2013), Lcerebok i utlendingsrett. Universitetsforlaget, Oslo, Norway.

8 In Tampere in 1999, Eu leaders committed to establish a Common European Asylum System (CEAS), The first phase of the CEAS was completed in 2006 under the Hague Program setting out the framework for a Common European Asylum System. A second phase of the harmonization process was completed in 2013 by the final adoption of the recast of the EU directives and regulations on asylum. See further European Parliament (2013), Parliament gives green light to the new European asylum system (press release).

9 F. Bøckman Finstad, 'EUs justis- og innenrikspolitikk', 25 Nytt Norsk Tidsskrift (2008) 336-347 at 340 . 
in December 2010. ${ }^{10}$ The return of irregular migrants is currently at the core of Norway's priorities, and the Government has developed a Return Strategy for the period 2011-2016. This strategy aims at furthering comprehensive and result-oriented returns, speedy returns, and sustainable return solutions. ${ }^{11}$ Following Norway's intensification of its return work, the number of forced returns doubled between 2006 and 2011, topped 4902 in 2012, and reached an all-time high in 2013 with 5934 returns. ${ }^{12}$

Norway appears highly motivated to maintain close contact and coordination with the EU's return policy. One clear expression of this policy is the 2009 White Paper on Norwegian Refugee and Migration Policy in a European Perspective, which also recognizes that policy developments in the EU will influence Norway. ${ }^{13}$ It stresses Norway's participation in Frontex, the European bureau for border control in charge of coordination of operationalizing returns to countries of origin. ${ }^{14}$ Frontex operations are a part of the Schengen cooperation, and approximately one half of the 26 chartered flights used by Norway to return irregular migrants in 2010 were Frontex Joint Return Operations. ${ }^{15}$ To keep updated on general developments in European migration policy, Norwegian institutions have also joined the European Migration Network (EMN), an initiative aimed at intensifying European cooperation in matters of migration. ${ }^{16}$ In June 2013, Norway additionally finalized working arrangements

10 See European Union Directive 2008/115/EC on common standards and procedures in Member States for returning illegally staying third-country nationals (2008); Norwegian Parliament (2010-2011), Vedtak til lov om endringer i utledningsloven (gjennomføring av returdirektivet), Lovvedtak 33, doc. No. Innst. 137 L (2010-2011).

11 Ministry of Justice and the Police (JD) (2011), Strategi for returområdet 2011-2016. See also JD. Prop 1 S (2012-2013), supra note 4, Table 2.31 'Utvikling i antall tvangsreturer 2006-2011'. JD. Prop 1 S (2012-2013), Table 2.25; Norwegian Directorate of Immigration, Varrkonferensen 2013: Retur (2013); National Police Immigration Service (PU) (2013), Månedsstatistikk desember 2013: Uttransporteringer fra Norge.

13 JD (2009), White Paper on Immigration, supra note 5. A summary in English is available online at http://www.regjeringen.no/upload/JD/Vedlegg/Faktaark/Migrasjonsmld_eng .pdf.

14 JD (2009), White Paper on Immigration, supra note 5, at 79.

15 See European Migration Network (EMN)/Norwegian Directorate of Police (PD) (2012), Practical Measures for Reducing Irregular Migration: the case of Norway, at 45; JD. Prop $1 \mathrm{~S}$ (2012-2013), supra note 4, Table 2.31 'Utvikling i antall tvangsreturer 2006-2011'; Ministry of Justice and the Police (JD). Proposition to the Storting: Prop 1 S (2010-2011) (Prop 1 S (20102011)), at 103; JD. Prop 1 S (2011-2012), supra note 5, at 127; JD. White Paper on Immigration, supra note 5, para. 5.5.3; Ministry of Foreign Affairs (MFA) (2010), Arbeidsprogram for EU/ EØS-saker 2010/2011.

16 JD (2009), White Paper on Immigration, supra note 5, at 78. 
for its participation in the European Asylum Office (EASO), which is an EU agency aiming to enhance practical cooperation on asylum matters and help EU Member States fulfill their European and international obligations to give protection to people in need. This arrangement will inter alia allow Norway to participate in EASO's work and to be represented in the EASO Management Board as an observer. ${ }^{17}$

The conclusion of bilateral readmission agreements is one way that Norway has intensified its work on returns. ${ }^{18}$ It concludes amongst the highest number of readmission agreements in Europe, and the former center-left Government's 2009 Political Platform specifically stated that it shall:

... intensify [its] work to establish good return agreements, conduct a comprehensive and unified return policy and use [its] aid and development policy to support work with returns and reintegration of persons without legal residence in Norway. ${ }^{19}$

This focus is also maintained in the 2013 Political Platform of the newly elected Government formed by the Conservative Party and the Progress Party. ${ }^{20}$

The conclusion of readmission agreements essentially aims to influence the migration flows both to and from Norway. Here, as well as in the EU, such agreements intend to reduce irregular presence (by increasing the number of returns), and discourage future irregular migration (by sending a clear signal to individuals without protection needs that they might be returned when their asylum applications are rejected). ${ }^{21}$ The agreements are technical instruments

17 EASO (2013), Norway, Switzerland, Lichtenstein and Iceland finalise working arrangements for their participation in the work of EASO. Press release, Doc. No. 05/2013.

18 See, for instance, Ministry of Labour (AD) (2005), Styrker innsatsen for integrering av innvandrere. Press Release no. 6.

19 Government of Norway (GoN) (2009), Political Platform as Basis for the Government's Work, formed by the Labour Party, Socialists Left Party and Centre Party, 2009-2013 (Political Platform), at 80 .

20 GoN. (2013), Political Platform for a government formed by the Conservative Party and the Progress Party, 7 October 2013 .

21 Ministry of Labour and Social Inclusion. Proposition to the Storting: St. prp. nr. 1 (20082009), at 328, Table 6.8; AD. (2005), Styrker innsatsen, supra note 18; EMN/PD. (2012), Practical Measures, supra note 15, at 13; National Police Immigration Service (PU) (2012), Strategi 2012-2016, at 5; JD (2009), White Paper on Immigration, supra note 5, para. 10.13; Commission of the European Communities (2002), Green Paper on a Community Return Policy on Illegal Residents, Doc. no. Сом (2002) 175 final, at 23; Commission of the European Communities (2003), On the Development of a Common Policy on Illegal 
aimed at improving the cooperation between administrations, and can only be used after a return decision has been made in accordance with the guarantees inter alia set out by the Directive on Return.

Although Article 23 of the Schengen Convention explicitly refers to readmission agreements and provides that aliens must be expelled from the territory of the contracting party in which they were apprehended, the European Council concluded in March 2000 that readmission agreements were not Schengenrelevant. ${ }^{22}$ Rather, EU readmission agreements have been considered to fall under the Eu's external policies. The associated Schengen countries (Norway, Iceland, Switzerland and Lichtenstein) are not parties to the EU's foreign policy and do not as such officially participate in the negotiation of EU readmission agreements. As this article will suggest, however, the Eu's work on readmission has a considerable impact also on Norway's readmission practice.

After it was decided that EU readmission agreements ${ }^{23}$ would not form part of the Schengen acquis, the European Commission, authorized to enter into readmission agreements on behalf of EU member states, ${ }^{24}$ included in all its EURAs a joint declaration which encourages countries with which it signs agreements to enter into corresponding agreements with the associated Schengen countries, including Norway. The Norwegian government has also made clear that it wishes to rely on the readmission agreements concluded by the EU and to negotiate similar agreements with countries with which the EU already has concluded EURAs. ${ }^{25}$ Since the spring of 2010, Norway and the European Commission meet yearly for consultations on readmission

Immigration, Smuggling and Trafficking of Human Beings, External Borders and the Return of Illegal Residents, Doc. no. сом (2003) 323 final, at 8; Council of the European Union. (2011) Council Conclusions on Readmission, supra note 3. See also Coleman, supra note 1 at 57 .

22 For a general discussion, see Coleman, supra note 1.

23 While the EU has had competence to conclude readmission agreements with other states since the coming into force of the Treaty of Amsterdam in 1999, the Treaty on the Functioning of the European Union (TFEU) provides an express legal base to do so. Article 79 (3) provides: 'The Union may conclude agreements with third countries for the readmission to their countries of origin or provenance of third country nationals who do not or who no longer fulfil the conditions for entry, presence or residence in the territory of one of the Member States.'

24 It is worth noting that the EURAs which it negotiates do not bind all EU member states. While the United Kingdom and Ireland have the possibility to opt in or opt out, Denmark, which abstained completely from some aspects of the Treaty of Amsterdam, has to conclude its own bilateral readmission agreements.

25 JD (2009), White Paper on Immigration, supra note 5, para. 5·5·3. 
agreements. ${ }^{26}$ This practice signalizes a recent policy change in Norway's approach to the EU - from initially having the sole ambition to fulfill Norway's commitments in the Dublin- and Schengen cooperations, to a more active policy from 2008 onwards aimed at implementing the EU immigration and asylum acquis as a whole. ${ }^{27}$

Several outside observers have nevertheless expressed concern about the top-down approach when it comes to Norway's Schengen participation, and its increasing involvement in European asylum initiatives such as EMN and EAso. Eriksen has argued that the government's and administration's role is strengthened on behalf of the Norwegian Parliament. ${ }^{28}$ Sejersted and Vevstad have similarly pointed out that Norway's relationship to the EU's Justice and Home Affairs, which subsumes Schengen, is characterized by frequent change, legal complexity and, often, a lack of public debate. ${ }^{29}$ Amid a development in which it is increasingly unclear which processes are Schengen-relevant and which are not $-\mathrm{EU}$ readmission practice being a case in point - Norway is formally excluded from some decision-making developments, yet often chooses to align itself with broader EU policies. As this article will show, the EU has begun to construct policy packages not confined to one policy area alone, and the Schengen cooperation becomes only one part of the package. This development has proven to be particularly challenging for associated states such as Norway. ${ }^{30}$

\section{Norway's Readmission Agreements: Target Countries and Scope}

\subsection{Introduction}

This section introduces Norway's readmission agreements and compares Norway's target countries with those of the European Union. By exploring the agreements in light of the EURAs, it also examines Norway's readmission agreements in terms of scope and content.

26 JD (2010), Gjennomføringsplan for utlendingsfeltet, at 35; MFA (2010), Arbeidsprogram, supra note 15 .

27 Brekke (2011), Migrasjon og integrasjon, supra note 5, at 7.

28 E.O. Eriksen, 'Norges demokratiske underskudd', 25 Nytt Norsk Tidsskrift (2008) 368-379 at 373 .

29 F. Sejersted, 'Norges rettslige integrasjon i EU', 25 Nytt Norsk Tidsskrift (2008) 313-322 at 316; Vevstad (2006), supra note 5 , at 18.

$30 \quad$ MFA (2005), St. meld. 23 (2005-2006) Om gjennomforing av europapolitikken, at 21; Bøckman Finstad (2008), supra note 9 at 337. 


\subsection{Target Countries}

Norway's first readmission agreement in modern time was signed with the Federal Republic of Germany in 1955. This was followed by a readmission clause embedded in the 1990 visa facilitation agreement with the Czech Republic. Norway's initial agreements and negotiations were largely ad hoc in nature, and it was only with the agreement with Romania, signed in 2002, that a comprehensive and result-oriented readmission policy began to materialize. ${ }^{31} \mathrm{In}$ 2005 alone, Norway entered into six readmission agreements, bringing the total number of readmission agreements, or other agreements containing a readmission clause, to 16 countries. ${ }^{32}$ This number has increased to 30 in 2013 , the most recent of which are with Tanzania, Georgia and Ethiopia. ${ }^{33}$ For an overview of the countries with which Norway has concluded readmission agreements, see Table 1.

Although the European Union has mostly targeted transit countries situated close to the EU's external borders, its first E URA was concluded with Hong Kong in 2002. A total of seven EURAs were signed in 2007, and, by early 2014, the EU had concluded agreements with 16 countries. With the exception of Macao, Pakistan, Cape Verde and Turkey, as Table 1 shows, all of these countries have concluded readmission agreements also with Norway. While many of these agreements are similar in scope and content to the standard EURA, as Section 2.4 will explain, some of Norway's agreements with these countries were signed or negotiated before the existence of a EURA.

Norway's and the EU's common interests are evidenced in the partial overlap of target countries. ${ }^{34}$ Norway's focus has in recent years lain steadily on approximately 20 states, including Algeria, Angola, Azerbaijan, Belarus, Democratic Republic of the Congo (DRC), Djibouti, Eritrea, Ghana, Guinea, Kazakhstan, Kirgizstan, Liberia, Macao, Mongolia, Morocco, Nepal, Nigeria, Pakistan, Somalia, Turkey, and Uzbekistan. ${ }^{35}$ Of these, EURAs already exist with Pakistan, Macao, and Turkey, while the European Commission is currently

31 Interview JD (12 September 2013). All interviews referred to in this article were confidential.

32 Ministry of Labour and Social Inclusion (AD). (2006), Norges landrapport til Migrasjonsutvalget (Norges landrapport), at 3 .

33 In 2010, Norway also signed a readmission agreement with Kazakhstan, but the agreement is not yet in force. See JD, Prop 1 S (2010-2011), supra note 15, at 186; JD. Prop 1 S (2011-2012), supra note 5, at 214; JD. Prop 1 S (2012-2013), supra note 4, at 117; Table 2.2 'Tilbaketakelsesavtaler'.

34 MFA (March 2013), Arbeidsprogram EU/EØS-saker 2013 (Arbeidsprogram), at 58.

35 See e.g., MFA (2013) Arbeidsprogram, supra note 34, at 58; JD. Prop 1 S (2010-2011), supra note 15, at 186; JD. Prop 1 S (2011-2012), supra note 5, at 214; JD. Prop i S (2012-2013), supra note 4 , at $117 ; 199$. 


\begin{tabular}{|c|c|c|c|c|}
\hline Country & $\begin{array}{l}\text { Date of signature } \\
\text { (Norway) }\end{array}$ & In force (Norway) & $\begin{array}{l}\text { Date of signature } \\
\text { (EU) }\end{array}$ & In force $(\mathrm{EU})$ \\
\hline $\begin{array}{l}\text { Federal Republic of } \\
\text { Germany }\end{array}$ & 18 March 1955 & 18 March 1955 & $\mathrm{~N} / \mathrm{A}$ & $\mathrm{N} / \mathrm{A}$ \\
\hline Czech Republic & 12 July 1990 & 12 July 1990 & $\mathrm{~N} / \mathrm{A}$ & $\mathrm{N} / \mathrm{A}$ \\
\hline Estonia & 14 January 1997 & 11 May 1997 & $\mathrm{~N} / \mathrm{A}$ & $\mathrm{N} / \mathrm{A}$ \\
\hline Latvia & 15 May 1997 & 1 July 1997 & $\mathrm{~N} / \mathrm{A}$ & $\mathrm{N} / \mathrm{A}$ \\
\hline Lithuania & 15 December 1992 & 15 December 1992 & $\mathrm{~N} / \mathrm{A}$ & $\mathrm{N} / \mathrm{A}$ \\
\hline Bulgaria & 16 December 1998 & 26 September 1999 & $\mathrm{~N} / \mathrm{A}$ & $\mathrm{N} / \mathrm{A}$ \\
\hline Sri Lanka & 6 March 2000 & 6 March 2000 & 4 June 2004 & 1 May 2005 \\
\hline Romania & 17 July 2002 & 24 July 2003 & $\mathrm{~N} / \mathrm{A}$ & $\mathrm{N} / \mathrm{A}$ \\
\hline Sweden & 18 December 2003 & 18 December 2003 & $\mathrm{~N} / \mathrm{A}$ & $\mathrm{N} / \mathrm{A}$ \\
\hline Croatia & 24 January 2005 & 30 July 2005 & $\mathrm{~N} / \mathrm{A}$ & $\mathrm{N} / \mathrm{A}$ \\
\hline Slovakia & 15 February 2005 & 28 May 2005 & $\mathrm{~N} / \mathrm{A}$ & $\mathrm{N} / \mathrm{A}$ \\
\hline Moldova & 31 March 2005 & 9 August 2006 & 10 October 2007 & 1 January 2008 \\
\hline Switzerland & 16 June 2005 & 22 September 2005 & $\mathrm{~N} / \mathrm{A}$ & $\mathrm{N} / \mathrm{A}$ \\
\hline Bosnia-Herzegovina & 30 June 2005 & 25 November 2007 & 18 September 2007 & 1 January 2008 \\
\hline Afghanistan & 10 August 2005 & 10 August 2005 & $\mathrm{~N} / \mathrm{A}$ & $\mathrm{N} / \mathrm{A}$ \\
\hline Hong Kong & 15 September 2006 & 1 January 2007 & 27 November 2002 & 1 March 2004 \\
\hline FYR Macedonia & 25 September 2006 & 21 June 2007 & 18 September 2007 & 1 January 2008 \\
\hline Russia & 8 June 2007 & 1 December 2008 & 25 May 2006 & 1 June 2007 \\
\hline Vietnam & 29 June 2007 & 4 July 2007 & $\mathrm{~N} / \mathrm{A}$ & $\mathrm{N} / \mathrm{A}$ \\
\hline Ukraine & 13 February 2008 & 1 September 2009 & 18 June 2007 & 1 January 2008 \\
\hline Albania & 12 September 2008 & 1 May 2009 & 14 Apr. 2005 & 1 May 2006 \\
\hline Burundi & 10 March 2009 & 10 March 2009 & $\mathrm{~N} / \mathrm{A}$ & $\mathrm{N} / \mathrm{A}$ \\
\hline Iraq & 15 May 2009 & 15 May 2009 & $\mathrm{~N} / \mathrm{A}$ & $\mathrm{N} / \mathrm{A}$ \\
\hline Montenegro & 16 December 2009 & 16 December 2009 & 18 September 2007 & 1 January 2008 \\
\hline Armenia & 20 January 2010 & 26 June 2010 & 19 Apr. 2013 & Not in force \\
\hline Kazakhstan & 12 October 2010 & Not in force & $\mathrm{N} / \mathrm{A}$ & $\mathrm{N} / \mathrm{A}$ \\
\hline Tanzania & 5 April 2011 & 5 April 2011 & $\mathrm{~N} / \mathrm{A}$ & $\mathrm{N} / \mathrm{A}$ \\
\hline Georgia & 10 November 2011 & 25 January 2012 & 22 November 2010 & 1 March 2011 \\
\hline Ethiopia & 26 January 2012 & 26 January 2012 & $\mathrm{~N} / \mathrm{A}$ & $\mathrm{N} / \mathrm{A}$ \\
\hline Macao & $\mathrm{N} / \mathrm{A}$ & $\mathrm{N} / \mathrm{A}$ & 10 October 2007 & 1 January 2008 \\
\hline Pakistan & $\mathrm{N} / \mathrm{A}$ & $\mathrm{N} / \mathrm{A}$ & 26 October 2009 & 1 December 2010 \\
\hline Cape Verde & $\mathrm{N} / \mathrm{A}$ & $\mathrm{N} / \mathrm{A}$ & 18 Apr. 2013 & Not in force \\
\hline Turkey & $\mathrm{N} / \mathrm{A}$ & $\mathrm{N} / \mathrm{A}$ & 16 December 2013 & Not in force \\
\hline
\end{tabular}


negotiating with Azerbaijan and Morocco, and attempting to formally commence negotiations with China and Algeria. ${ }^{36}$ As for Turkey, Norway's Ministry of Foreign Affairs (MFA) has previously stated that as soon as the Turkish EURA is concluded, it will 'immediately' follow up and initiate negotiations for a corresponding agreement. ${ }^{37}$ Such statements have previously been put forward also with regard to Pakistan, but no Norwegian agreement with Pakistan exists to date.

However, Norway seeks to conclude readmission agreements with all states with which it has a 'migration relation', and as the above listing also shows, it aims to also conclude agreements with countries where no EURA or negotiating directive exists. ${ }^{38}$ Countries are selected on the basis of the number of returns from Norway; which countries it is facing challenges with when it comes to readmitting individuals; and an evaluation of which countries it expects that a readmission agreement would facilitate return to. ${ }^{39}$ Norway's focus on concluding readmission agreements with countries in the Horn of Africa is an example of this; an agreement with Ethiopia was recently concluded and Somalia/Somaliland, Djibouti and Eritrea are amongst its top priorities. None of these countries have been explicitly prioritized on the EU-level, although, as we shall see in Section 3.4, the EU included Ethiopia in its Global Approach to Migration and Mobility (GAMM). ${ }^{40}$

In 2012, the E U's Joint Readmission Committee began identifying new target countries. Norway participated in this Committee and proposed countries with which it is facing challenges in readmission negotiations. ${ }^{41}$ The country recommendations varied considerably among the Committee members, and there was substantial scepticism also in the Strategic Committee on Immigration, Frontiers and Asylum about granting the Commission new negotiating

36 See JD (July 2012), EUs Innenriksområde: Oppsummering fra første halvår 2012 (Oppsummering), at 26; European Commission. Evaluation of Readmission Agreements, supra note 1 at 6 . See also C. Billet, 'EC Readmission Agreements: A Prime Instrument of the External Dimension of the EU's Fight against Irregular Immigration: An Assessment after Ten Years of Practice', 12 European Journal of Migration and Law (2010) 45-79 at 56.

37 See MFA (June 2011), Arbeidsprogram EU/EØS-saker 2011/2012 (Arbeidsprogram), at 48; MFA. (2013) Arbeidsprogram, supra note 34, at 58; JD (2009), Justis- og Innenriksfeltet: Halvårsrapport fra EU-delegasjonen høsten 2009.

38 JD (2009), White Paper on Immigration, supra note 5, para. 5.5·3; JD. Prop 1 S (2012-2013), supra note 4, para. 4.2.

39 JD (2010), Gjennomføringsplan, supra note 26 , at 35 .

40 PU (2009), Årsmelding 2009, at 10.

41 JD (2012), Oppsummering, supra note 36 at 26. 
mandates. ${ }^{42}$ Among the issues was a fear that EU negotiations with certain third states with which specific EU member states already had functioning bilateral readmission agreements (case in point: Afghanistan) would have the potential of creating more problems than they would solve. At present there is somewhat of an impasse within the EU as to the form of future EURAs, and the European Commission has suggested that readmission agreements should no longer be devised in a stand-alone fashion, but rather be a part of a coherent package. Such a package would include other incentives such as various visa related policy tools, financial assistance, and elements of the Global Approach to Migration 'toolbox'.43 These issues and their implications for Norway are discussed further in Section 3.

That said, the already existing EURAs have a tangible impact on Norway's readmission policies, and it is to this topic that we now turn.

\subsection{The Joint Declaration Concerning (Iceland and) Norway}

As previously mentioned, the European Commission has been mandated to enter into readmission agreements with third countries on behalf of EU member states. Norway is not a part of this arrangement, but the Commission asks third countries with which it enters into agreements to also enter into similar readmission agreements with Norway. ${ }^{44}$ All EURAs therefore contain a standard joint declaration stating that it would be 'appropriate' for Iceland and/or Norway to conclude a bilateral readmission agreement with the third country concerned. The Joint Declaration Concerning Iceland and Norway specifically provides that:

The Contracting Parties take note of the close relationship between the European Community and Iceland and Norway, particularly by virtue of the Agreement of 18 May 1999 concerning the association of these countries with the implementation, application and development of the Schengen acquis. In such circumstances it is appropriate that $[\ldots]$ conclude a readmission agreement with Iceland and Norway in the same terms as this Agreement.

Some have questioned the practical impact of this declaration, claiming that it has not led to any tangible results when it comes to Norway's negotiations

\footnotetext{
42 JD (2012), EUs Justis og Innenriksområde: Oppsumering fra andre halvår 2012, at 25.

43 European Commission. Evaluation of Readmission Agreements, supra note 1 at 7.

44 JD (2009), White Paper on Immigration, supra note 5, para. 10.11.
} 
with third states with which EURAs exist. ${ }^{45}$ Rather, scholars such as Brekke assert that Norwegian state officials have worked independently to negotiate and conclude agreements with third states. Even though this declaration admittedly is more a political gesture than it is legally binding, contrary to the above assertions, this article argues that its effect is clearly noticeable in the Norwegian context. Even before the standard EURA was fully elaborated, Norway also expressed an expectation that the inclusion of such a declaration in future EURAs would facilitate Norway's negotiations with the third countries concerned. ${ }^{46}$

The EURAs appear to have influenced Norwegian readmission practice in three important ways. First, and as Section 3.2 will show, many of the EURAs are linked to visa facilitation agreements. In contrast to the EURAs, these visa facilitation agreements are considered Schengen-relevant. This essentially means that Norway, to ensure harmony in the Schengen-system, is under an obligation to enter into similar visa facilitation agreements. In concluding such agreements, it is clearly in Norway's interest to also conclude interlinked readmission agreements. Thus, through the Eu's visa facilitation agreements, Norway is closely, albeit indirectly, associated to the EURAs. Second, Norwegian fear persists of receiving considerable asylum flows from countries where a EURA, but no Norwegian readmission agreement, is in place. Authorities, dreading augmented pressure on the Norwegian asylum system, actively seek to use the EURA declaration..$^{47}$ Even though most of the countries with which there exists a EURA were not initially strategically important to Norway, it aims to conclude readmission agreements with these countries as a preventative strategic policy in order to pre-empt future problems. ${ }^{48}$ In the words of one informant, these agreements are simply 'bonus agreements' in addition to the more 'important' agreements which are grounded in more immediate Norwegian concerns. ${ }^{49}$ This relates to the third reason for Norway to enter into corresponding agreements: while Norway's conclusion of many of these agreements can not necessarily be seen as a response to any particular Norwegian

\footnotetext{
45 Brekke (2011), supra note 5 at 16.

46 AD (2006), Norges landrapport, supra note 32 at 3.

47 Interview JD (12 September 2013), See also JD (2009), White Paper on Immigration, supra note 5, para. 5.5.3; JD. Prop 1 S (2012-2013), supra note 4, Table 2.2 'Tilbaketakelsesavtaler'; JD. Prop 1 S (2011-2012), supra note 5, at 214; AD (2009), Proposition to the Storting: St. prp. nr. 1 (2009-2010) (St. prp. Nr. 1 (2009-2010)), at 319; JD. Prop 1 S (2010-2011), supra note 15, at 187; Department of Municipal and Regional Development, St. prp. nr. 1 (2005-2006), at 89 .

48 Interviews JD (13 and 18 September 2013).

49 Interview JD (13 September 2013).
} 
concerns, they are important from a long-term perspective. Its agreements with, for example, Macao and Hong Kong may appear irrelevant in today's context, but Macao may prove to be essential in Norway's attempts to negotiate readmission with states such as China. Through these agreements, Norway hopes to penetrate strategically important regions, and expects that negotiations with one country will be facilitated if that country's neighbor already has entered into a readmission agreement with Norway. ${ }^{50}$

Today, Norway follows EU developments closely in order to evaluate which types of agreements would be beneficial also for Norway. In cases where Norway and the EU have parallel negotiations with third states, information and experience are often exchanged between them. ${ }^{51}$ Norway and the EU have had parallel negotiations with Georgia, and, more recently, with Azerbaijan. While Norway began its negotiations with Georgia long before the EU, due to a prolonged Norwegian-Georgian stalemate concerning the format of one specific wording, the EU caught up and Norway ended up concluding its agreement one year after the conclusion of the EURA. ${ }^{52}$ As for Azerbaijan, Norway faced considerable difficulties initiating negotiations, but these were eased once the EU began its negotiations, and both agreements are expected to be concluded shortly. Equally, once the EURA with Russia was in place, Norway's lengthy negotiations with Russia were facilitated and a corresponding agreement was concluded within a year. ${ }^{53}$ Norway's agreement with Ukraine was also concluded within a year of the EURA, its agreements with Serbia and Montenegro within two, Albania within three, and Hong Kong within four. As we will see below, all of these agreements with the exception of Georgia are strikingly similar to their corresponding EURAs.

\subsection{Norwegian Readmission Agreements: Clear EURA Influence}

While it is clear that Norway has concluded readmission agreements with 12 of the 15 countries with which the EU has a EURA, its agreements with Sri Lanka, Moldova, Armenia, Macedonia and Bosnia and Herzegovina were concluded

$50 \quad$ Interview JD (18 September 2013).

51 MFA (2008), Betydningen av EUs migrasjonspolitikk for Norge (Fred-Olav Sørensen, «spesialråd migrasjon», the Norwegian Mission to the EU, 29 November 2007); JD. Prop 1 S (2012-2013), supra note 4, Table 2.2 'Tilbaketakelsesavtaler'; JD. Prop 1 S (2011-2012), supra note 5, at 214; JD. Prop 1 S (2010-2011), supra note 15, at 187.

$5^{2}$ Interview JD (18 September 2013).

53 Department of Municipal and Regional Development and Norwegian Directorate of Immigration (UDI) (November 2002), Nyhetsbrev om norsk flyktning- og innvandringspolitikk, 9(41); AD. (2006), Norges landrapport, supra note 32 at 3 . 
before EURAs existed with these countries. With the exception of Georgia, where Norwegian negotiations began before the Commission's negotiations, all of Norway's agreements that were concluded with third states after the conclusion of a EURA (i.e. Ukraine, Russia, Serbia, Montenegro, Albania and Hong Kong) essentially follow the structure and content laid out in the corresponding EURA.

The European Commission strives to conclude uniform readmission agreements, and the fact that most of the EURAs are identically structured indicates that it to a large extent succeeds in this aim. ${ }^{54}$ Most EuRAs commence with a preamble and define certain notions, before being structured in eight sections. With the exception of Norway's agreement with Ukraine, whose corresponding EURA comprises seven sections, all Norwegian agreements are in this respect made up of eight sections. Section I sets out the readmission obligations of the third contracting party and Section II does so in an identical manner for the European Union/Government of Norway. ${ }^{55}$ Section III describes the operational readmission procedure and sets time limits, application procedure and means of evidence, etc. Section IV deals with transit operations, Section V with the allocation of costs, and Section VI holds a non-affection clause along with a specific provision for data protection. Section VII of the Norwegian agreements with Serbia, Albania, Montenegro and Hong Kong differs - for obvious reasons - from Section VII of the corresponding EURAs in that the Norwegian agreement has two articles on 'Joint Expert Group' (or 'Expert Meetings' as in the case of Montenegro) and 'Implementing Provisions', while the EURA has three articles: 'Joint Readmission Committee', 'Implementing Protocols' and 'Relation to Bilateral Readmission Agreements or Arrangements of Member States'. An article on 'Territorial Application' which is inserted in the EURA's final provisions of Section VIII is also missing in the corresponding Norwegian agreements with Serbia, Albania, Montenegro and Russia. Neither the EURA nor the Norwegian agreement with Hong Kong appears to include a provision on 'Territorial Application'. In the case of Ukraine, which has one section less than most other readmission agreements, the EURA includes an article on 'Relation to Bilateral Readmission Agreements or Arrangements of Member

54 For an overview of the most difficult issues to agree upon in EURA negotiations, see F. Trauner and I. Kruse, 'EC Visa Facilitation and Readmission Agreements: A New Standard EU Foreign Policy Tool?', 10 European Journal of Migration and Law (2008) 411438 at 429 .

55 Note, however, that the EURAs with Ukraine and Pakistan hold seven sections; Sections I and II are addressed jointly in the first section. For an analysis of the standard draft EURA and all its provisions, see generally Coleman, supra note 1 at 87-109. 
States' in Section VI, and an article on 'Territorial Application' in Section VII, neither of which is found in the corresponding Norwegian agreement. Finally, there are annexes which contain common lists of documents that prove nationality or the fulfilment of the conditions for readmission, as well as a model document to launch the readmission application. In most cases, these annexes are not included in Norway's agreements, and neither are references to third-country nationals.

The European Union's influence on Norway's readmission practice is perhaps most interestingly noted with respect to Norway's agreements with Tanzania and Kosovo, as well as its not-yet-in-force agreement with Kazakhstan. While no corresponding EURA exists for these three cases (and Norway was thus not explicitly encouraged to follow a certain form), it has chosen to follow the standard EURA structure in these agreements. Its agreement with Tanzania essentially follows its agreement with Ukraine (in turn based on the corresponding EURA), while the agreement with Kosovo follows the standard eight-section EURA. In all of these cases, it was Norwegian state officials who proposed the usage of the standard EURA. ${ }^{56}$ From their perspective, there are good reasons to follow the EURA structure; the EURA is seen as a 'safe' and 'reliable' agreement that has been meticulously drafted on the EU-level and is thus unlikely to contain any unexpected or unpleasant loopholes. ${ }^{57}$ Because the EURA is extensive in scope, Norwegian state officials also find the agreement attractive to bring to the negotiating table simply because it, as opposed to other less substantial readmission agreements, can be reduced during negotiations. It is well-known that it is decisively more difficult during negotiations to add, rather than to remove, clauses. In this sense, the EURA is unquestionably used by Norway as part of its negotiating strategy.

\subsection{Non-EURA-Related Agreements}

Norway has also concluded readmission agreements with a number of countries that have not entered into corresponding agreements with the EU. While these agreements essentially fall outside the scope of this article, a few words must nevertheless be said. Croatia, Bulgaria, the Czech Republic, Estonia, Latvia, Lithuania, Romania, Sweden, Slovakia, and Switzerland are all part of, or will soon be part of, the Schengen cooperation. ${ }^{58}$ Nationals of Schengen

\footnotetext{
$5^{6} \quad$ Interview JD (18 September 2013).

57 Interview JD (18 September 2013); MFA (2 October 2013).

$5^{8}$ Croatia, joining the EU in 2013, is expected to have joined the Schengen Area by 2015, while Romania and Bulgaria's bids to join the Schengen area were approved by the European Parliament in 2011 but rejected by the Council of Ministers that same year.
} 
countries are guaranteed free movement within the Schengen area. Moreover, the forced return of third-country nationals to EU- or Schengen-associated countries with which Norway has a readmission agreement is conducted with the use of directives such as the Return Directive. This means that any underlying bilateral agreements are not used in these cases.

More interesting are perhaps Norway's agreements with Afghanistan, Sri Lanka, Burundi, Ethiopia, Iraq, Tanzania and Vietnam. Together with Norway's agreement with Kosovo, its agreements with Iraq and Afghanistan have been considered to be the most successful of Norway's agreements - the agreement with Afghanistan, which is a tripartite agreement with the United Nations High Commissioner for Refugees (UNHCR), has for example resulted in the return of approximately five individuals per week. ${ }^{59}$ The Sri Lankan agreement, on the other hand, made up of a brief correspondence laying out a total of five articles, was only in force for a two-year period and targeted primarily a very narrow group of individuals whom Norway wanted to return to Sri Lanka. ${ }^{60}$

In contrast to Norway's EURA-related agreements, which as mentioned earlier are comprehensive and relatively straightforward, several of Norway's other readmission agreements are purposely ambiguous. Although Norway's agreement with Iraq, for example, is not confidential, it has been deliberately withheld from all websites providing public access to Norwegian bilateral agreements and other legislation. ${ }^{61}$ Upon Iraqi request, the agreement has also been drafted in a manner that aims at downplaying, and ends up effectively concealing, the fact that it concerns the forced return of Iraqi nationals. This attempt to intentionally draft an ambiguous agreement is also evident in Norway's Ethiopian agreement, the draft proposal for which Ethiopia brought to the negotiating table. From the perspective of third states, this approach is understandable; readmission agreements mainly bring about negative consequences for concerned third states, and politicians who actively assist in the forced return of their country's nationals (i.e. promote these types of readmission agreements) may risk losing significant parts of their electorate. As one Norwegian state official points out, however, because these equivocal agreements do not clarify what was agreed during the readmission negotiations, they are often difficult to implement in practice. ${ }^{62}$ For the purposes of predictability and legal certainty, it would therefore appear preferable that Norway more persuasively advocated for the application of the standard EURA, as it has done

\footnotetext{
59 Interview JD (18 September 2013).

6o Interview JD (12 September 2013).

61 Interviews JD (12 and 18 September 2013).

62 Interview JD (18 September 2013).
} 
in the cases of Tanzania, Kosovo and Kazakhstan. Doing so might also address some of the human rights concerns which have been raised with regard to a few of these agreements. The Ethiopian agreement has notably been criticized by Norwegian human rights organizations and the United Nations Office of the High Commissioner for Human Rights (UN OHCHR) alike for falling short on a number of core human rights standards. ${ }^{63}$

\subsection{Conclusions}

As this section has shown, there are several ways in which important aspects of Norway's readmission strategy are developed in response to, and influenced by, the EU strategy on readmission. First, as part of a preventative strategic policy, Norway seeks to conclude readmission agreements with countries with which EURAs exist. With the exception of Georgia, all of Norway's agreements that were concluded with third states after the conclusion of a EURA essentially follow the structure and content laid out in the corresponding EURA. Second, through the many EU visa facilitation agreements that are paired with the EURAs, and in order to ensure harmony in the Schengen system, Norway is obligated to enter into visa facilitation agreements with these same states. Because it is usual in these situations to also negotiate readmission, the visa facilitation agreements form an indirect link between EU and Norwegian readmission agreements. Third, Norway attempts to use the EURA format as a basis for negotiations also with countries with which no EURAs exist. It has succeeded in doing so in its agreements with Tanzania, Kosovo and Kazakhstan.

Finally, despite the fact that EURAs are considered non-Schengen-relevant, and Norway is formally excluded from important decision-making processes, by participating in forums such as the EU Joint Readmission Committee, Norway also has a limited opportunity to influence EU readmission policy.

\section{$4 \quad$ Integrating Readmission into External Relations}

\subsection{Introduction}

This section explores how readmission agreements relate to EU and Norwegian external relations. It begins by discussing the relation between visa facilitation

63 UN онснг (2012), Communication from Special Procedures: Allegation Letter; JD (2012), Re: Memorandum of Understanding between Norway and Ethiopia.; NOAS (2012), 13 Months of Sunshine?, Rapport fra NOAS' faktasøkende reise til Etiopia; NOAS, and Save the Children Norway (2012), Returavtalen med Etiopia - barn som mister foreldre. All on file with author. 
and readmission, and continues with an examination of how Norway's readmission agreements relate to its external relations and development aid policies. Finally, it examines Norway's participation in the EU Global Approach to Migration and Mobility (GAMM).

\subsection{Linking Readmission to Visa Facilitation}

Norway's early readmission agreements were explicitly linked to the lifting of visa requirements. As many other European states during the 1990s, Norway was concerned that the lifting of visa requirements might lead to an increase in unauthorized entry ${ }^{64}$ Readmission agreements were therefore concluded in parallel as a compensating safeguard, or, as in the cases of the Czech Republic and Lithuania, readmission was incorporated into a clause in the visa facilitation agreement itself. Early on, the conclusion of readmission agreements with all countries in the Western Balkans, including Kosovo, proved to be a prerequisite for opening up for visa facilitation for these same countries. ${ }^{65}$

When negotiations on EU readmission agreements first commenced in 2001, however, the initial approach was to negotiate readmission agreements with third countries without offering anything in return. In order to convince third states to enter into readmission arrangements with the $\mathrm{EU}$, it was nonetheless soon forced to develop a set of incentives. ${ }^{66}$ The link between visa facilitation and readmission was made for the first time with the Russian Federation and the Ukraine, where negotiations really only materialized once the EU had committed to negotiate visa facilitation agreements in parallel. Since then, visa facilitation has been a requisite for many third states in return for their cooperation when it comes to readmission agreements, and visa negotiations have been frequently combined from the very beginning of the readmission negotiations. ${ }^{67}$ By 2013, the $\mathrm{EU}$ had signed visa facilitation and readmission agreements with 11 countries: Albania, Armenia, Bosnia and Herzegovina, Cape Verde, Former Yugoslav Republic of Macedonia (FYROM), Georgia, the Republic of Moldova, Montenegro, Russia, Serbia and Ukraine. ${ }^{68}$

\footnotetext{
64 Coleman, supra note 1 at $16 \mathrm{ff}$.

65 MFA (2010), Meld. St. 17 (2010-2011), Norsk innsats for stabilitet og utvikling i SørøstEuropa (White Paper on Norway's Efforts for Stability and Development in Southeastern Europe), para. 4.6.

66 Trauner and Kruse (2008), supra note 54, at 415.

$67 \quad$ Ibid. at 416.

68 The exact content of these agreements vary, but many include visa facilitation or reduced visa costs for certain categories of citizens (typically diplomats), or simply facilitated visa procedures. See JD (2009), White Paper on Immigration, supra note 5, para. 5·5·3.
} 
Today, Norway has once again strengthened the linkage between visa facilitation and readmission agreements. ${ }^{69}$ To ensure harmony in the Schengencooperation's visa policies, where the EU has entered into visa facilitation agreements with third states, Norway has essentially been under an obligation to negotiate similar bilateral agreements with these same states. ${ }^{70}$ Out of the 11 countries for which there exists both a EURA and a corresponding Norwegian agreement, as Table 2 shows, Norway has signed paired visa facilitation agreements with nine: Albania, Armenia, Bosnia-Herzegovina, Montenegro, Republic of Macedonia, Moldova, Russia, Serbia, and Ukraine. Georgia is seemingly the only state with which Norway and the EU both have readmission agreements but where the EU also has a visa facilitation agreement and Norway does not.

\subsection{Readmission and External Relations}

As previously indicated, readmission agreements and forced return mainly bring about negative consequences for concerned third countries. ${ }^{71}$ Unless they receive something worth more in return, these states seldom find it worth cooperating in readmission. To counter the difficulties faced by both Norway and the EU when negotiating readmission agreements, readmission has been increasingly incorporated into external relations and linked to development aid. Such agreements are also incorporated in broader bilateral cooperative frameworks which often include other strategic policy areas such as security, energy and trade. ${ }^{72}$ As we will see, however, the linking of readmission to external relations within both Norway and the EU is not unproblematic. ${ }^{73}$

Even though the Norwegian administration of immigration has frequently been transferred from one ministry to the other and is divided between several departments and directorates, ${ }^{74}$ the government has ever since the $1990 \mathrm{~s}$ attempted to create greater cooperation between national authorities working with immigration issues and the MFA working with foreign aid and development. Norway's readmission agreements are today drafted in cooperation

\footnotetext{
69 JD (2010), Gjennomføringsplan, supra note 26, at 35 .

$70 \quad$ MFA (2011), Arbeidsprogram, supra note 37 at 48.

71 Trauner and Kruse (2008), supra note 54, at 431-434; MFA (2007), Betydningen av, supra note 51 .

72 J.P. Cassarino (2010), Readmission Policy in the European Union, Strasbourg: European Parliament, at 25 .

73 See, for instance, JD (2009), White Paper on Immigration, supra note 5, para. 6.2. See also Brekke (2011), supra note 5, at 16; J.P. Brekke (2001), Velkommen og farvel?: midlertidig beskyttelse for flyktninger i Norge, Oslo: Institute for Social Research.

74 AD (2006), NOU 2006:14 Gransking av Utlendingsdirektoratet, at 61.
} 


\begin{tabular}{lllll}
\hline Country & $\begin{array}{l}\text { Date of signature } \\
\text { (Norway) }\end{array}$ & In force (Norway) & $\begin{array}{l}\text { Date of signature } \\
(\mathbf{E U})\end{array}$ & In force (EU) \\
\hline Czech Republic & 12 July 1990 & 1 January 1993 & N/A & N/A \\
Estonia & 7 Apr. 1997 & 1 May 1997 & N/A & N/A \\
Latvia & 2 July 1997 & 1 August 1997 & N/A & N/A \\
Lithuania & 15 December 1992 & 15 December 1992 & N/A & N/A \\
Russia & 8 June 2007 & 1 December 2008 & 25 May 2006 & 1 June 2007 \\
Ukraine & 13 February 2008 & 1 September 2011 & 18 June 2007 & 1 January 2008 \\
Albania & 1 May 2008 & 1 May 2009 & 18 September 2007 & 1 January 2008 \\
Bosnia-Herzegovina & 22 July 2008 & 1 May 2009 & 18 September 2007 & 1 January 2008 \\
FYR Macedonia & 28 July 2008 & 1 February 2009 & 18 September 2007 & 1 January 2008 \\
Montenegro & 16 December 2009 & 16 December 2009 & 18 September 2007 & 1 January 2008 \\
Serbia & 30 November 2009 & Not in force & 18 September 2007 & 1 January 2008 \\
Kazakhstan & 12 October 2010 & Not in force & N/A & N/A \\
Moldova & 14 September 2011 & 1 December 2011 & 10 October 2007 & 1 January 2008 \\
Armenia & 9 November 2011 & 15 March 2012 & 17 December 2012 & Not in force \\
Georgia & N/A & N/A & 17 June 2010 & 1 March 2011 \\
Cape Verde & N/A & N/A & 16 October 2012 & Not in force \\
& & & & \\
\hline
\end{tabular}

between the MFA and the Ministry of Justice and Public Security (JD). The MFA leads negotiations with certain countries - it is currently negotiating with Somalia, Eritrea, and Djibouti, and was the lead agency for negotiations with Ethiopia - while the JD leads readmission negotiations with essentially all other states. ${ }^{75}$ The MFA also leads the Coordination Committee for Readmission Agreements which includes representatives from the JD, the Ministry of Labour, the Norwegian Directorate of Immigration, and the National Police Immigration Service. ${ }^{76}$ Additionally, Norway practices a system of Immigration Liaison Officers (ILOs), in which Norwegian officials are posted to Norwegian embassies abroad in order to establish and maintain contacts with the authorities of the host country with a view to contributing to the

75 Personal communication, JD (30 September 2013).

76 For an example of earlier coordination groups, see Department of Municipal and Regional Development and UDI (2002), Nyhetsbrev (...), supra note 53 . 
prevention of illegal immigration. ${ }^{77}$ Some of these officers are explicitly tasked with strengthening Norway's return work, inter alia to assist in concluding and implementing readmission agreements. ${ }^{78}$ In 2012, Norway had Immigration Liaison Officers focusing on return in Algeria, Thailand, Ethiopia and Jordan. ${ }^{79}$ The system was evaluated in 2011, and the evaluation concluded that these officers indeed contributed to an increased number of returns and facilitated the negotiation of readmission agreements. ${ }^{80}$

For a long time, however, no reciprocities were linked to the readmission agreements. ${ }^{81}$ This approach changed with the issuance of the report Migration and Development - Better Context and Coordination in 2006. Here, an interdepartmental working group recommended the closer integration of readmission agreements and development aid. ${ }^{82}$ This view was also mirrored in the centerleft government's 2009 Political Platform, which clearly stated that it shall 'use [its] aid and development policy to support work with returns and reintegration of persons without legal residence in Norway', and explained that is has also earmarked resources to develop efforts which would make 'poor countries' more inclined to enter into readmission agreements with Norway. ${ }^{83}$ Together with the EU, Norway also participates in the Global Forum on Migration and Development (GFMD), where it is a member of the steering group and participates regularly in working groups and G FMD's annual conference. ${ }^{84}$

When it comes to implementing this policy in practice, however, there appears to be a prevailing idea amongst state officials that the policy has not led to any tangible results. ${ }^{85}$ Several informants claim that there is not a single

77 See, e.g., JD, Prop 1 S (2012-2013), supra note 4, at 3.5.3; Ministry of Labour and Social Inclusion, Proposition to the Storting: St. prp. $n$ r. 1 (2008-2009), at 329.

78 See, e.g., JD, Prop 1 S (2011-2012), supra note 5, at 212; JD, Prop 1 S (2010-2011), supra note 15, at 104; AD. (2009), St. prp. nr. 1 (2009-2010), supra note 47, at 318.

79 JD, Prop 1 S (2012-2013), supra note 4, Table 2.31 "Utvikling i antall tvangsreturer 20062011". See also Ministry of Labour and Social Inclusion, Proposition to the Storting: St. prp. $n r .1$ (2008-2009), at 328-329; JD, Prop 1 S (2011-2012), supra note 5, at 212.

$80 \quad$ JD, Prop 1 S (2012-2013), supra note 4, at 3.5.3.

81 AD and MFA (May 20o6), Migrasjon og utvikling - bedre sammenheng og samordning: Rapport fra en tverrdepartemental arbeidsgruppe, para. 4.9.

82 Ibid.

83 GoN (2009), Political Platform, supra note 19 at 80;JD (2009), White Paper on Immigration, supra note 5 , paras. 9.6; 10.11. See also AD (2009), St. prp. nr. 1 (2009-2010), supra note 47, at 21 .

84 EMN (2011), Annual Policy Report 2011 Norway - Report to the European Migration Network from the Norwegian Contact Point, EMN Report 2(11), at 39.

85 Interviews JD (12, 13 and 18 September 2013); MFA (20 September 2013). 
example of where the policy to link readmission and development aid has resulted in anything concrete, and one informant insinuates that as of today, this link is merely political wishful thinking. ${ }^{86}$ State officials within the MFA equally describe the attempts at linking the two fields as deeply sensitive and strenuous. ${ }^{87}$ While the center-left Political Platform was unveiled in 2009, no real attempts at tackling the issue were made within the MFA until 2012, when in the aftermath of the controversial White Paper on Children Seeking Protection ${ }^{88}$ an internal working group was tasked with examining the issue more closely. ${ }^{89}$ Due to deep political divisions, however, this initiative is yet to deliver any meaningful development.

This perceived gap between theory and practice has been ascribed by policymakers mainly to two factors. First, two very different mandates underpin, and create a certain tension between, the respective entities - the immigration authorities function with the aim of overcoming challenges in the national arena, while the focus of the MFA has largely been on the best interests of third states. ${ }^{90}$ According to certain state officials, the issue of forced return, and as such also readmission agreements, is seen as murky and to a great extent incompatible with the culture and spirit amongst many officials working with development aid. ${ }^{91}$ Linking readmission agreements to development aid is believed to undermine basic principles of development aid and poverty reduction. ${ }^{92}$ These officials describe a deeply rooted resistance to linking forced return with development aid, and a fear that development aid will become conditional upon the conclusion of readmission agreements. Making aid conditional upon the conclusion of readmission agreements appears nevertheless to be a welcome development amongst several state officials within the JD, who also point to the Netherlands as an example of good practice in this regard. ${ }^{93}$ A second, related, explanation is allegedly found in the Norwegian political landscape as it was prior to the general elections in the autumn of 2013, where one found a coalition government consisting of the Labour Party, Centre Party, and Socialists Left Party. The post of Minister of International Development

\footnotetext{
86 Interviews JD (18 September 2013); MFA (20 September 2013).

87 Interview MFA (20 September 2013).

88 JD (2011), Meld. St. 27 (2011-2012) Barn på flukt (White Paper on Children Seeking Protection).

89 Interview MFA (20 September 2013).

9o Brekke (2011), supra note 5 , at 16 . See also Brekke (2001), Velkommen og farvel, supra note 73 .

91 Interview JD (12 September 2013).

92 Interview MFA (20 September 2013).

93 Interviews JD (12,13 and 18 September 2013).
} 
was held by a representative of the Socialists Left Party, and because this Party has austerely resisted any linking of readmission agreements and development aid, there is a general perception that its dominance in the realm of Norwegian development aid functioned as an effective stumbling block against the implementation of this wider political goal. ${ }^{94}$

Norway's 2012 agreement with Ethiopia is a prominent example of the ambiguous relationship between readmission and development aid. After Norway had attempted to negotiate a readmission agreement with Ethiopia for approximately two decades, agreement was finally reached in February $2012 .{ }^{95}$ A few months earlier, Norway had agreed to donate approximately 350 million Norwegian kroner to forestry, energy- and agricultural projects in Ethiopia. This donation stirred certain media attention considering that it was in addition to the 200 million Norwegian kroner the Government already had committed to, and despite the fact that countries such as Sweden, in response to Ethiopia passing a number of 'anti-human rights' laws, chose to considerably reduce its development aid to Ethiopia. Norwegian authorities were subsequently fiercely accused of trading development aid for readmission, but representatives of both the JD and the MFA persistently denied any link between the two. ${ }^{96}$ There appears to be a widespread conviction amongst state officials in the JD that there was no intentional link on the part of Norway between the readmission agreement and the increase in development aid. ${ }^{97}$ Norwegian state officials have rather argued that Norway, in contrast to the European Commission and 'being a small country', has little leverage when it comes to negotiating the conclusion of readmission agreements. ${ }^{98}$ Instead of threatening to withdraw development aid, or using such aid as an incentive for countries to conclude readmission agreements, Norway allegedly aims to capitalize on the negotiating party's conscience and reputation. It may for example argue that if country $x$ fails to negotiate readmission with Norway, nationals of country $x$ engaged in criminal activity in Norway may risk tainting country $x$ 's global reputation. Norway may also play to the conscience of country $y$ and

94 Interviews JD (18 September 2013); MFA (20 September 2013).

95 Department of Municipal and Regional Development, St. prp. nr. 1 (2005-2006), at 90.

96 H. Hegtun et al. (17 March 2012), Doblet støtten til Etiopia før avtalen ble signert. Aftenposten; Nтв (17 March 2012), Norge doblet Etiopia-støtte rett før returavtale. Dagsavisen; Mariam, A.G. (26 March 2012), No Way for Ethiopian Refugees in Norway, blog post available online at http://open.salon.com/blog/almariam/2012/03/25/no_way_ for_ethiopian_refugees_in_norway.

97 Interviews JD (12, 13 and 18 September 2013).

$98 \quad$ Interview JD (18 September 2013). 
reason that because Norway financially or otherwise supports it, it would 'be of tremendous help to Norway if country $y$ gives back just a little bit' ${ }^{\prime 9}$ These views are particularly interesting against the message conveyed in the newly elected Government's Political Platform that the Government shall '... use Norway's position to secure a greater number of such agreements.'100

That said, it remains unclear to what extent, if at all, Norway's development aid may have de facto affected Ethiopia's decision to enter into the readmission agreement. The eventual impact of Norway's participation in the EU's cooperation platform with Ethiopia (see Section 3.4) is also unclear, but Norwegian state officials unanimously claim that there was no connection between the conclusion of the readmission agreement and Norway's participation in the platform. ${ }^{101}$ This next section may offer clarity as to why they would argue this.

\subsection{Norway and the EU Global Approach to Migration and Mobility}

Norway also participates - albeit thus far to a limited extent - in various aspects of the EU's external migration policy. While there was initial scepticism about linking return and readmission to external relations also within the EU, it has ever since the mid-20oos systematically integrated its migration policy's external dimension in both external relations and development aid. ${ }^{102}$ In 2011, the European Council even called for the EU readmission policy to be more embedded in the overall external relations policy of the EU. ${ }^{103}$ An important trend is currently to negotiate with individual countries of origin on the basis of an entire package of measures, including readmission agreements. ${ }^{104}$ This policy finds expression in the Global Approach to Migration and Mobility (GAMM), which has been described as 'a comprehensive approach [combining] measures aimed at facilitating legal migration opportunities with those reducing illegal migration'. ${ }^{105}$ The Global Approach may be seen as the

\footnotetext{
99 Interview JD (18 September 2013).

100 Emphasis added. GoN. (2013), Political Platform for a government formed by the Conservative Party and the Progress Party, 7 October 2013.

101 Interviews JD (12, 13 and 18 September 2013); MFA (20 September 2013).

102 JD (2009), White Paper on Immigration, supra note 5, para. 8.2; Coleman, supra note 1 at $111 \mathrm{ff}$.

103 Council of the European Union (2011), Council Conclusions on Readmission, supra note 3 , at 3 .

104 European Commission, The Global Approach to Migration One Year On: Towards a Comprehensive European Migration Policy, сом (2006) 735 final, at 9.

105 European Council (2007), Council Conclusions on the Global Approach to Migration, 2807th Council Meeting, Justice and Home Affairs. Luxembourg, 12 and 13 June 2007, at 3. See also Cassarino (2010), supra note 72 , at 36 .
} 
overarching framework for the EU external migration policy, complementary to the EU foreign policy and development cooperation. The EU readmission policy forms an integral part of the Global Approach. ${ }^{106}$

Under the panoply of the Global Approach, the EU has developed several parallel models which all form an integral part of the Approach: mobility partnerships, cooperation platforms for migration and development, and Migration Information and Management Centers. While the mobility partnership, which arose from the EU-Africa meeting in Rabat in 2006, is the most formalized model of migration partnership, the cooperation platforms for migration and development are the least formal. ${ }^{107}$ Cooperation platforms are characterized by a structural dialogue between the partnership country and the EU in which efforts are made to both strengthen control over migration including cooperation on readmission - and economic development. While only one platform exists to date, signed with Ethiopia in 2007, since that same year the European Commission has been invited by the Council to launch pilot mobility partnerships with a few countries. The EU entered into mobility partnerships with Moldova and Cape Verde in 2008, with Georgia in 2009, Armenia in 2011 and Morocco in 2013. It has specifically attempted to link mobility partnerships with cooperation on readmission, and today, EuRAs exist with all of these countries but Morocco.

In February 2009, the EU and Ethiopia established a cooperation platform for migration and development, and Norway was soon invited to join this UK-led initiative. ${ }^{108}$ According to one informant, this invitation was extended to Norway after it had reached out to the European Commission and clearly expressed a will to participate in appropriate aspects of the GAMM. ${ }^{109}$ Participation in the EU's cooperation platform in general, and its cooperation platform in Ethiopia in particular, seemed appropriate to Norway for several reasons. The 2009 White Paper on Norwegian Refugee and Migration Policy in a European Perspective conveys great expectations about how Norway will be able to benefit from being part of such comprehensive efforts: 'when [Norway's actions] are coordinated with other European states, there is

106 Council of the European Union (2011), Council Conclusions on Readmission, supra note 3 , at 2 .

107 JD (2009), White Paper on Immigration, supra note 5, para. 8.2.3.

108 JD (2009), White Paper on Immigration, supra note 5, para. 8.2.3. See also A. Weinar (2011), EU Cooperation Challenges in External Migration Policy, Research Report EU-US Immigration Systems 2011/02, EUI, at 8.

109 Interview JD (18 September 2013), See also JD. White Paper on Immigration, supra note 5, para. 9.6. 
reason to hope for greater effects both in terms of migration control and the region's development.'110 However, its participation in the EU cooperation platforms does not entail any legally binding agreements. This informal nature is a core reason for why Norway could participate in this EU initiative, where the Schengen-cooperation was merely one small aspect embedded within a larger package containing mostly EU external relations. ${ }^{111}$ The informal nature of cooperation has not, however, hindered a Norwegian expectation that participation in such a platform may further the conclusion of more Norwegian readmission agreements. ${ }^{12}$ Furthermore, in stark contrast to the EU's mobility partnerships with countries such as Moldova, Georgia and Armenia, which are only tangentially important to Norwegian external relations and development aid, Ethiopia, and the Horn of Africa in general, is a clear priority in the work of both the MFA and the JD. ${ }^{113}$ Norway receives many asylum seekers from the Horn of Africa and the region is also important for Norwegian external relations and development aid. The MFA and the JD cooperate in defining Norway's contribution to the EU cooperation platforms. ${ }^{114}$ The fact that readmission (and development aid) was not to be negotiated in a stand-alone fashion as explained earlier, but rather as one aspect of a larger strategy, must have appeared more preferable to the MFA. ${ }^{115}$

Approximately 10 countries participated in the EU-Ethiopian cooperation platform, but it soon became clear that it was difficult for these to agree upon the strategy and the focus of the platform. ${ }^{116}$ Apart from differences in opinion amongst the EU-members, Ethiopia allegedly aggravated the cooperation by a series of what were perceived as willful misunderstandings about the nature and form of readmission to Ethiopia. When the platform fizzled out in 2010, despite attempts from Sweden to rescue it, Norway had only participated in two meetings. The catastrophe that one must admit the cooperation platform in Ethiopia turned out to be has nevertheless not discouraged Norway from aiming to participate in future cooperation initiatives. Recognizing that participating in EU cooperation partnerships brings forth a new dimension to Norway's cooperation with the EU, the Norwegian government has expressed

\footnotetext{
110 JD (2009), White Paper on Immigration, supra note 5, para. 9.6.

111 Interview JD (18 September 2013).

112 JD (2009), White Paper on Immigration, supra note 5, para. 9.6.

113 MFA (2009), Interests, Responsibilities and Opportunities. The main features of Norwegian foreign policy, Report No. 15 2008-2009.

114 JD (2009), White Paper on Immigration, supra note 5, para. 9.6.

115 Interview MFA (20 September 2013).

116 Interview JD (12 September 2013).
} 
an expectation that initiatives similar to the EU-Ethiopia cooperation platform will be taken also with other countries in the region. ${ }^{117}$ Following the conclusion of EU's mobility agreement with Morocco in mid-2013, Morocco allegedly floated the idea of a Norwegian-Moroccan cooperation along the lines of what was laid out in the EU-Moroccan mobility agreement. ${ }^{118}$ Considering that North Africa is an increasingly prioritized region for Norwegian politics, these developments will be interesting to follow.

\subsection{Conclusions}

This section has examined how readmission agreements relate to Norwegian and EU external relations. It has shown how the integration of readmission agreements and development aid is a clear political goal for the Norwegian government, and how Norway's external migration policies and activities are increasingly linked to the work of the EU. Norway's participation in the EU's GAMM is nevertheless limited by two important factors. First, the GAMM is a policy package firmly placed within EU external relations and is thus only tangentially within the Schengen cooperation. This means that Norway is limited to participation of a less formal nature, i.e. cooperation platforms rather than mobility partnerships. Second, Norway's participation may also be limited by internal political perceptions about linking readmission and development aid. The prevailing view amongst influential actors in the realm of Norwegian development aid is that the linking of readmission agreements to development aid undermines basic principles of poverty reduction. This view appears to function as an effective stumbling block against the implementation of the wider political goal to link readmission agreements and development aid.

\section{5}

\section{Conclusions}

The aim of this article has been to offer an analysis of the objective and substance of Norway's readmission agreements in light of European Union readmission policies. The analysis has shown how Norwegian readmission practice is far from being disconnected from overall EU policies; in many respects Norway's practice is a direct outcome of such policies. Readmission policy developments on the EU level specifically impact Norway's practice in three important ways. First, as part of a preventative strategic policy, Norway seeks to conclude readmission agreements with countries with which EU readmission

\footnotetext{
117 JD (2009), White Paper on Immigration, supra note 5, para. 9.6.

118 Interview JD (18 September 2013).
} 
agreements (EURA) exist. With the exception of Georgia, all of Norway's agreements that were concluded with third states after the conclusion of a EURA essentially follow the structure and content laid out in the corresponding EURA. Second, EU visa facilitation agreements that are paired with EURAS form an indirect link between $\mathrm{EU}$ and Norwegian readmission agreements. To ensure harmony in the Schengen system, Norway is obligated to enter into visa facilitation agreements with these same states. The negotiation of readmission agreements almost always follows the conclusion of such visa facilitation agreements. Third, Norway uses the EURA-format as a basis for negotiations even with countries where no EURA exists, such as in the cases of Tanzania and Kazakhstan.

This article also examined Norway's participation in the EU Global Approach on Migration and Mobility. It finds that although the integration of readmission agreements and development aid is a clear government policy, Norway's participation in initiatives such as GAMM is limited by the GAMM being only tangentially within the Schengen cooperation, and also by national political perceptions about linking readmission and development aid.

\section{Acknowledgement}

The author is a researcher on the VAM-project 'Migration to Norway. Flows and Regulations', financed by the Research Council of Norway. 